\title{
Protease from Courgette (Luffa Acutangula L (Roxb)): Isolation, Purification, and Some Characteristics
}

\author{
MIKE PERMATA SARI ${ }^{1}$, DWIRINI RETNO GUNARTI ${ }^{2}$, MOHAMAD SADIKIN ${ }^{* *}$ \\ ${ }^{I}$ Master Program in Biomedical Sciences, Faculty of Medicine, Universitas Indonesia, Jakarta Pusat 10430 \\ ${ }^{2}$ Department of Biochemistry and Molecular Biology, Faculty of Medicine, Universitas Indonesia, Jakarta Pusat \\ 10430
}

Diterima 17 June 2019/Disetujui 20 August 2019

\begin{abstract}
The Courgette or oyong (Luffa Acutangula L. (Roxb)) is member of Cucurbitaceae mainly used as vegetable. Beside used as vegetables, courgette aslo used as keratolytic agent. This fact is supposed that this vegetables contain protease. This research is succeed to purified courgette's protease by four step. That was precipitate by $70 \%$ ammonium sulphate saturation, purification using DEAE cellulose ion exchange chromatography and gel filtration chromatography using sephadex G-100 and G-75. Purified courgette's protease had 81,922 U/mg for specific activity and $34 \mathrm{kDa}$ molecular weight. This enzyme had the characteristic such as activated optimally at $37^{\circ} \mathrm{C}, \mathrm{pH} 7$ and 10 minute duration time. This enzyme activity can decrease by $\mathrm{PMSF}$ and $\mathrm{H}_{2} \mathrm{O}_{2}$, its remarkable that courgette protease is serine protease and had the thiol group in its structure. The ability to digest food proteins materials like boiled meat and boiled white egg by courgette protease proves that the courgette protease enzyme is could be used in enzyme replacement therapy in mild digestion problem.
\end{abstract}

Key words: Characteristic protease, Courgette, Luffa acutangula L (Roxb), protease purification, serine protease

\section{INTRODUCTION}

Protease is one of hydrolases class enzyme, that is able to break peptide bonds on various types of proteins by hydrolysis and converting proteins into simple peptides or single amino acids. (Naidu 2011) Protease has many roles in physiology, it is also widely used for several objective. Proteases are widely distributed in nature, as in animal, both in plant and microorganism. In present study, the use of protease from plants is still focused to bromelain from pineapple (Ketnawa et al. 2011) and papain from papaya (Amri and Mamboya 2012). However, several studies were done on other sources especially from Cucurbitaceae class. It was realized in cucumber (Nafeesa et al. 2017), melon (Devi and Hemalatha 2014), pumpkin (Dąbrowska et al. 2013), Bitter gourd (Wang et al. 2008), and Chayote (Ratnayani and Lia 2011). some of them are use traditionally for cosmetics objectives.

The Courgette or oyong (Luffa Acutangula L. $($ Roxb)) is member of Cucurbitaceae mainly used as vegetable. Courgette is used in Indonesia beside as vegetable also as cosmetics agent, I.a as keratolytic agent in tradiotionals facial cure. Because of the fact that courgette is member of Cucurbitaceae, and

${ }^{*}$ Penulis korespondensi:

E-mail: sadikinmohamad@gmail.com because it is use as keratolytic agent, it is supposed that this vegetable contain protease.

The purpose of our study is to detect and isolate and characterize protease in the courgette.

\section{MATERIALS AND METHODS}

Material. The courgette were purchased from a farm near Jakarta and the species was determined in Indonesian Institue of Science (Center of Plant Conservation Botanic Garden). The chemicals are gelatin, $\mathrm{KH}_{2} \mathrm{PO}_{4}, \mathrm{~K}_{2} \mathrm{HPO}_{4}, \mathrm{NaCl}, \mathrm{TCA}$, Sodium carbonate $\left(\mathrm{Na}_{2} \mathrm{CO}_{3}\right)$, Folin Ciocalteus reagent, L-tyrosine, DEAE cellulose, sephadex G-100 and G-75, Tris-HCl, SDS, Coomassie brilliant blue R-250, glycerol, glycine, methanol, acetic acid, acrylamide, N, N' bisacryl, Ammonium persulphate, Calsium chloride $\left(\mathrm{CaCl}_{2}\right)$, Zinc Chloride $\left(\mathrm{ZnCl}_{2}\right)$, Magnesium Chloride $\left(\mathrm{MgCl}_{2}\right)$ and Cupro Chloride $\left(\mathrm{CuCl}_{2}\right)$, PMSF (Phenyl methyl sulfonyl fluoride), EDTA (Ethylendiaminetetra acetic), Iodoacetate, urea, $\beta$-mercaptoetanol and $\mathrm{H}_{2} \mathrm{O}_{2}$.

\section{Methode.}

Preparation of Crude Extract. $400 \mathrm{~g}$ of courgette were peeled, weighed and homogenized with a blender in $90 \mathrm{ml}$ of $0.05 \mathrm{M} \mathrm{pH} 7$ phosphate buffer. Then the homogenate was squeezed with flannel cloth and the juice obtained was centrifuged at $6,500 \mathrm{rpm}$ in $4^{\circ} \mathrm{C}$ for 60 minutes. 
Assay of Protease Activity. One mililiter of sample was incubated for 5 minutes in $37^{\circ} \mathrm{C}$ then $1 \mathrm{ml}$ of $1 \%$ gelatin substrate was added and the incubated continue for 10 minutes at the same temperature. The mixture was precipitated by addition of $2 \mathrm{ml} \mathrm{5 \%}$ TCA and incubated for 10 minutes at room temperature. The end of this period the mixture was centrifugeted $\left(6,500 \mathrm{rpm}, 4^{\circ} \mathrm{C}\right.$, 10 minute). $1 \mathrm{ml}$ supernatant was pippeted into a cup, followed by $5 \mathrm{ml}$ of $4 \% \mathrm{Na}_{2} \mathrm{CO}_{3}$ and $1 \mathrm{ml}$ of Folin-Ciocalteu reagent and incubating for at $37^{\circ} \mathrm{C}$. Absorbance was read at $660 \mathrm{~nm}$. As blank we use the supernatant precipitate immiditially with TCA then followed by substrate and then the mixture centrifuge. Supernatant was preceed with the same treatment as a sample.

Assay of Protein Total Concentration. Determination of protein concentration is read by Warburg methode, which measure the absorption at $280 \mathrm{~nm}$. As standard protein we used bovine serum albumin (BSA) concentration range from 0.1-0.5 $\mathrm{mg} / \mathrm{ml}$, distilled water as the blank.

\section{Purification Protease Enzyme.}

Protein Precipitation with Ammonium Sulphate. Two hundred milliliter were added ammonium sulphate crystals with a series of saturation $(30,50,70$, and $90 \%)$. The precipitates were collected after incubation at $4^{\circ} \mathrm{C}$ overnight and then centrifuged in $6,500 \mathrm{rpm}, 4^{\circ} \mathrm{C}$ during 1 hours. The precipitate was redissolved in $0.05 \mathrm{M}$ phosphate buffer $\mathrm{pH} 7$ untill it reaches a volume of $30 \mathrm{ml}$. The solution was dialzsed with distilled water for 24 hours at $4^{\circ} \mathrm{C}$. The protease activities and protein concentration were measured and the specific activity was calculated.

DEAE Cellulose Ion Exchange Chromatograpy. The dialysate with the highest specific activities was applied to DEAE cellulose coloumn $(20 \times 1.5 \mathrm{~cm})$. The sample was eluted with $0.05 \mathrm{M}$ phosphate buffer $\mathrm{pH} 7$ (without $\mathrm{NaCl}$ ) and followed by series the same buffer but containing a grading $\mathrm{NaCl}$ from $0.1-0.7 \mathrm{M}$. Fractions of 1.5 $\mathrm{ml}$ elution were collected and protein concentration was read at $280 \mathrm{~nm}$. Fraction forming a peak were collected and assayed for protease specific activity. The fraction with the highest protease activity was lyophilized. (Asker et al. 2013).

Gel Filtration on Sephadex G-100 and G-75. One hundred milligrams of the highest protease activity from DEAE cellulose peak was applied to sephadex G-100 coulomn $(20$ x1.5 cm). Sample was eluted by $0.05 \mathrm{M}$ phosphate buffer containing $0.4 \mathrm{M}$ $\mathrm{NaCl}$. G-100 peak with the highest specific activity was applied to sephadex G-75. (Gunarti 1997) The highest protease activity was lyophilized.
Polyacrylamide Gel Electrophoresis. Molecular weight was determined by nondenaturing electrophoresis and zymogram methode. Protein marker was used 10-250 kDa. (Nafeesa et al. 2017) Non denaturing electrophoresis was performed in polyacrylamide gel $10 \%$ at $90 \mathrm{~V}$ for 2 hours. Gelatin zymography was performed to test the proteolytic activity of the purified fraction with minor modifications polycarilamide gel $10 \%$ and co-polymerized with $0.5 \%$ gelatin. The sample were applied in non-reducing condition and run at $90 \mathrm{~V}$ for 2 hours in $4^{\circ} \mathrm{C}$. The gel was washed with $2.5 \%$ Triton $\mathrm{X}-100$ for 30 minute to remove SDS was incubated in $30 \mathrm{mM}$ Tris- $\mathrm{HCl} \mathrm{pH} 7.4,200 \mathrm{mM}$ $\mathrm{NaCl}$, and $10 \mathrm{mM} \mathrm{CaCl}$ for 1 hours. Gel was stained with Coomassie brilliant blue R-250 for 30 minute and then gel was washed with de-stained solution. Protease activity's area was appeared as non-stained clear band on a dark blue background.

Effect of Temperature, $\mathrm{pH}$ and Incubation Time on Enzyme Activity. To determine the optimum of $\mathrm{pH}$, temperature and incubation time, the enzyme was reacted with the gelatin substrate $1 \%$. The optimum incubation time was determine by incubating the mixture of enzyme-gelatin substrate, and the mixtures were stopped after various time (0-2 hours). (Wang et al. 2008) The optimum $\mathrm{pH}$ was determine by incubating the mixture in various $\mathrm{pH}$ ranging from 4 to 10 . The optimum temperature was studied by incubating the mixture in optimum $\mathrm{pH}$ and optimum incubation time with various temperature ranging from 4 to $90^{\circ} \mathrm{C}$. (Wang et al. 2008; Nafeesa et al. 2017).

Effect of Metal Ion and Inhibitors on Enzyme Activity. To determine the effect of metal ion and protease inhibitors in protease activity. Protease was treated with $\mathrm{CaCl}_{2}, \mathrm{ZnCl}_{2}, \mathrm{MgCl}_{2}$, and $\mathrm{CuCl}_{2}$ as metals ion and Iodoacetate, urea and EDTA as protease inhibitors. Each concentration of metals ion and inhibitors was 1 and $5 \mathrm{mM}$. (Sulistyowati et al. 2016; Nafeesa et al. 2017).

Effect of oxidizing and reducing agents on enzyme activity. To determine the effect of oxidizing and reducing agents. Protease activity was treated with $\mathrm{H}_{2} \mathrm{O}_{2}$ as oxidant agent, and $\beta$-mercaptoetanol as redactor agent. Each concentration for reductor and oxidizers is 1 and $5 \mathrm{mM}$.

Determination of $\mathbf{K m}$ and $V \max$ Value for the Protease Enzyme. To determine the reaction rate (Vmax) and the Michaelis-Menten $(\mathrm{Km})$ value, protease was reacted with gelatin substrate with a concentration range of $0.014-0.555 \mathrm{M}$ in $0.05 \mathrm{M}$ phosphate buffer solution $\mathrm{pH} 7$. The result was made in Lineweaver-burk curve. 
The Ability of Courgette Protease to Digest of Food Proteins. To determine the potential of protease to digest food protein. $0.5 \mathrm{~g}$ meat and egg were boiled with with $0.05 \mathrm{M}$ phosphate buffer solution $\mathrm{pH} 7$. Then the samples was incubate with crude and protease that had been purified for 5-60 minute. After incubation process was done, sample was weighed and tyrosine release was measured with activity protease procedure. The difference weight between before and after incubation and tyrosine release in medium must be recorded.

\section{RESULT}

Purification Protease. Crude extract were precipitate with ammonium sulphate with various saturation (Table 1). The result showed that the highest specific activity was measured in precipitate of $70 \%$ saturation. Therefore, the fraction of $70 \%$ saturation were used as starting material for following experiment.

Figure 1 shows the anion exchange using DEAE cellulose chromatography result. The highest activity was found in the fraction that eluted with phosphate buffer solution containing $0.4 \mathrm{M} \mathrm{NaCl}$, which is found in the fraction number $\mathrm{V}$. The highest specific activity from DEAE cellulose was applied to the gel filtration column with sephadex G-100 and G-75. Protease purification using sephadex G-100 resulted the two highest protein peaks. The highest specific protease activity was founded in fraction III presented in (Figure 2). Further molecular sieving chromatography using sephadex G-75 gave two highest peaks. The highest protease specific activity peak was founded in fraction II, which is presented in (Figure 3).

Figure 1 shows that from all of the three highest peaks, the peak with the highest protease activity is fraction number $\mathrm{V}$ with a protease activity 42,763 $\mathrm{U} / \mathrm{ml}$ and total protein concentration is $1,105 \mathrm{mg} /$ $\mathrm{ml}$. Therefore, the highest specific activity is in fraction number 5 with a value of $42,763 \mathrm{U} / \mathrm{mg}$.

Figure 2 shows that highest protease activity is in fraction number III, with the value of $63,715 \mathrm{U} /$ $\mathrm{ml}$ and total protein concentration is $0.923 \mathrm{mg} / \mathrm{ml}$. Therefore, the highest specific activity is $69,001 \mathrm{U} /$ mg.

Table 1 . Spesific activity after salting out and dialysis

\begin{tabular}{lllc}
\hline Fraction (\%) & $\begin{array}{l}\text { Total protein } \\
\text { concentration } \\
(\mathrm{mg} / \mathrm{ml})\end{array}$ & $\begin{array}{l}\text { Protease } \\
\text { activity } \\
(\mathrm{U} / \mathrm{ml})\end{array}$ & $\begin{array}{l}\text { Specific } \\
\text { activity } \\
(\mathrm{U} / \mathrm{mg})\end{array}$ \\
\hline 30 & 3,790 & 25,362 & 6,693 \\
50 & 7,692 & 40,744 & 5,297 \\
70 & 6,639 & 62,207 & 9,371 \\
90 & 2,731 & 5,586 & 2,045 \\
\hline
\end{tabular}

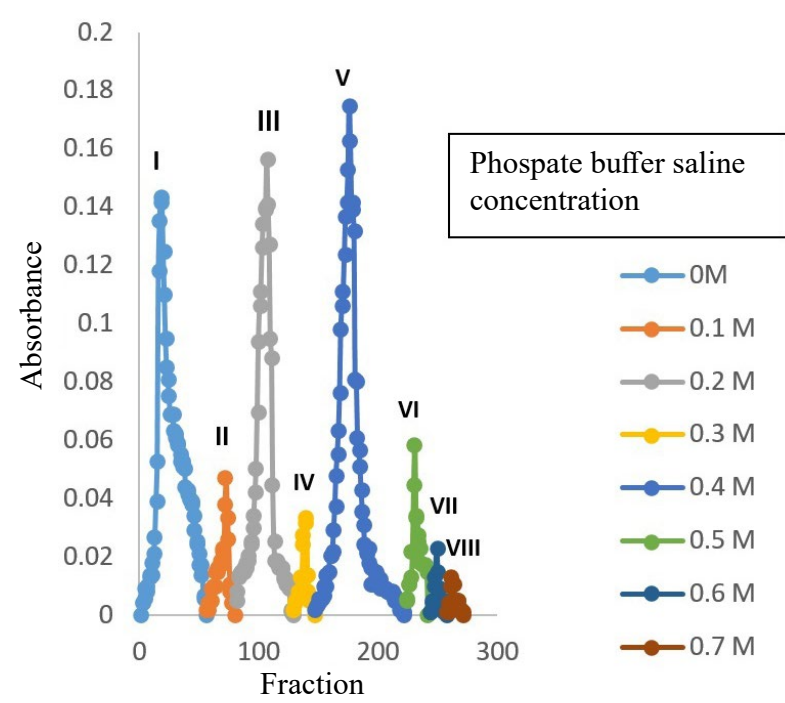

Figure 1. Fractionation using DEAE cellulose chromatography column using various buffer phosphate saline concentration

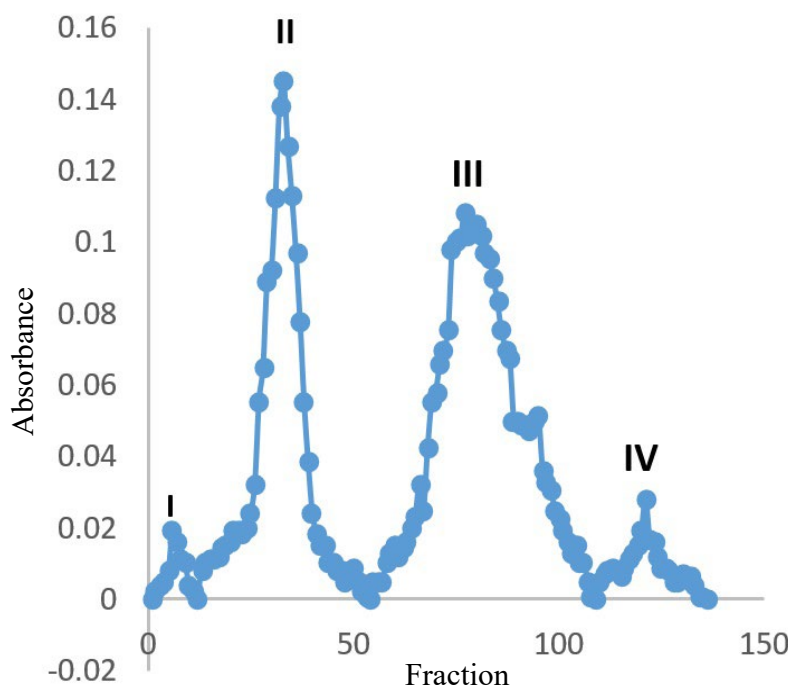

Figure 2. Fractionation with filtration gel column chromatography using sephadex G-100

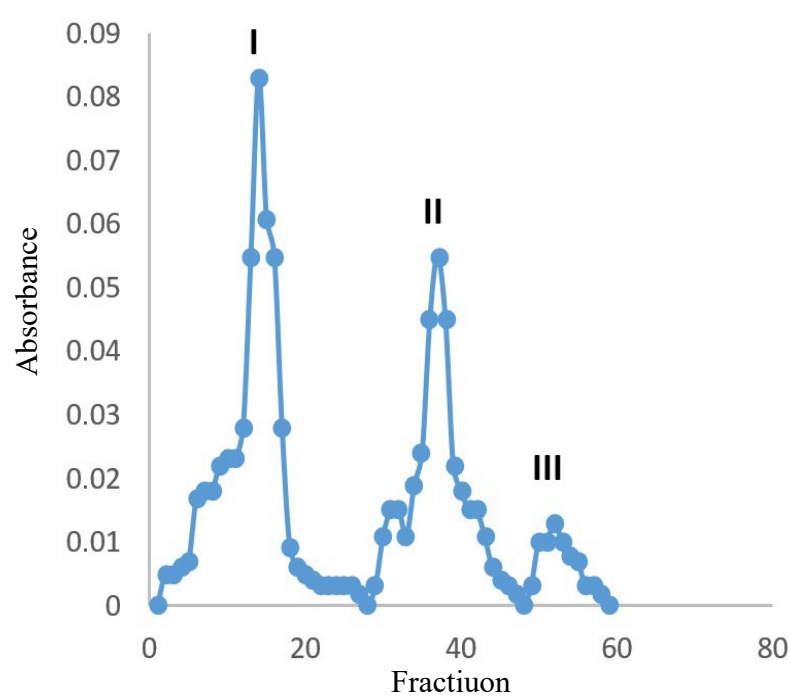

Figure 3. Fractionation with filtration gel column chromatography using sephadex G-75 
Figure 3 shows that there is the highest protease activity at peak II with an activity of 53,903 U/ml and a total protein concentration of $0,684 \mathrm{mg} / \mathrm{ml}$. therefore the specific activity obtained is 81,922 . from this figure it can be stated that there was an increase in specific activity after purification.

Protein Weight Determination. Purified courgette protease from sephadex G-75 chromatography $(\mathrm{G})$ had a single band of $34 \mathrm{kDa}$. The single band was resulted from standar curve semilog with the equation $y=-1,9012 x+5,328$. Protein weight determination was obtained using non-denaturing electrophoresis gel. The results of the gelatin zymogram show that there is a specific zone in the same position with a single band obtained in non-denaturing electrophoresis gel. Molecular weight of purified protease are presented in Figure 4.

Optimum Temperature, $\mathrm{pH}$ and Duration of Incubation Time. Figure 5 shows that courgette protease is active in the $\mathrm{pH}$ range 6-8. However the optimum $\mathrm{pH}$ at 7 with the highest activity is 144,661 $\mathrm{U} / \mathrm{ml}$.

Figure 6 shows that courgette protease had the highest activity at $37^{\circ} \mathrm{C}$ with activity value is 56,356 $\mathrm{U} / \mathrm{ml}$. While 40 and $50^{\circ} \mathrm{C}$ the activity is slowly decrease.

Figure 7 shows that optimum duration incubation time is 10 minute with the activity is $47,898 \mathrm{U} / \mathrm{ml}$.

Effect of Metal Ions and Protease Enzyme Inhibitors on Protease Enzyme Activity. There were no siginificant influences of the addition of various metal ions on enzyme activity. Some compound had various influences on enzyme activities. Urea, iodoacetate and EDTA practically had no influence at all. These suggest that the enzyme is a single polypeptide, neither a cysteine protease nor a metalloprotease. However PMSF had a clear inhibition, which suggest that the enzyme was a serine protease. The results were presented in Table 2.

Effect of Reducing and Oxidizing Agent to Enzyme Activity. Addition of $\mathrm{H}_{2} \mathrm{O}_{2}$ reduced the activities to $40 \%$ of control, whereas reducing agent as mercaptoethanol practically had no influence. The data suggest that the enzyme have reduced cysteine moiety for maintaining the proper structure. On the other hand, the enzyme did not contain intramolecular -S-S- bridge, as indicated by no influenced of mercaptoethanol. The results of this experiment are presented in Table 3.

Determination of $\mathrm{Vmax}$ and $\mathrm{Km}$. A lineweaverburk curve was constructed for determining $\mathrm{Km}$ and Vmax. The equation obtained was $\mathrm{y}=0.0002 \mathrm{x}+$ 0.0059 the calculated $\mathrm{Km}$ was $0.0339 \mathrm{M} / \mathrm{ml}$ and Vmax was $164,491 \mathrm{U} / \mathrm{M} /$ minute. The result was served in Figure 8.

The Ability of Protease Enzyme to Digest of Food Proteins. The aim of this experiment was to see if the courgette protease could be used in enzyme replacement therapy in mild digestion problem. Using boiling meat and boiling white egg. The result were evaluated in 2 ways by weighing periodically the incubated boiling meat and boiling white egg, and by reading tyrosine release into the medium at the same period. Figure 9 is presenting the weight reduction result and table 4 shows that protease could digest both food materials, and the
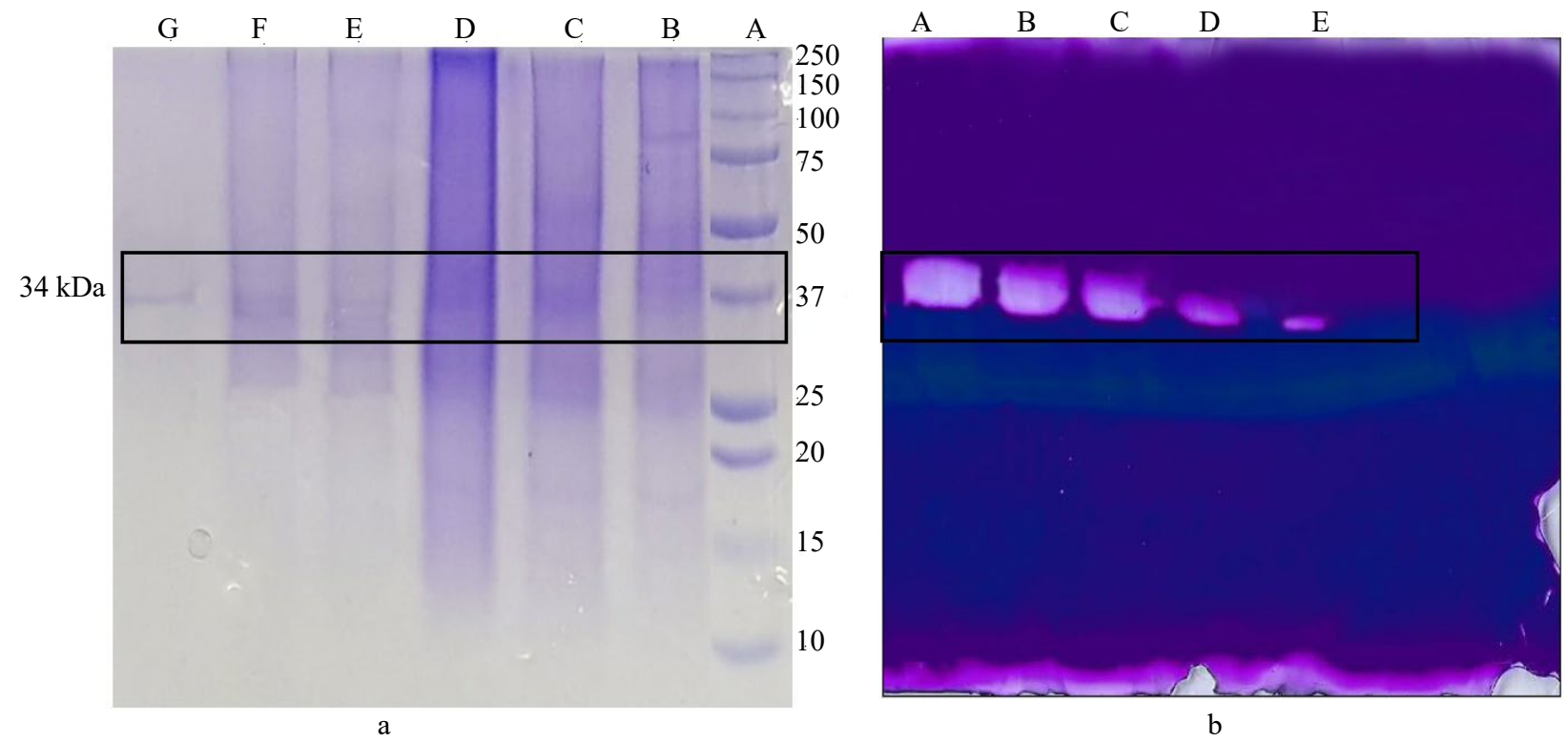

Figure 4. Protein weight determination using electrophoresis. (a) non denaturan electrophoresis result. A protein marker, B Crude, C Dialysate 70\%, D fraction V DEAE Cellulose, E and F. Fraction III sephadex G-100, G Fraction II sephadex G-75. (b) zymogram electrophoresis result A Crude, B Dialysate 70\%, C fraction V DEAE cellulosa, D Fraction III sephadex G-100, E Fraction II sephadex G-75 


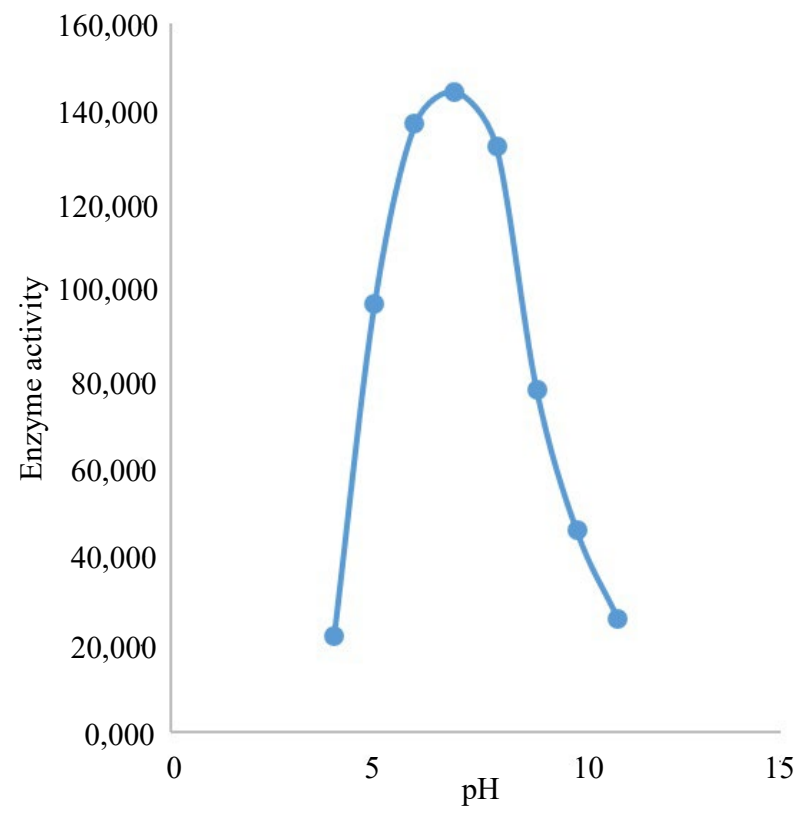

Figure 5. Effect of $\mathrm{pH}$ on protease enzyme activity. Activity is presented in enzymes units

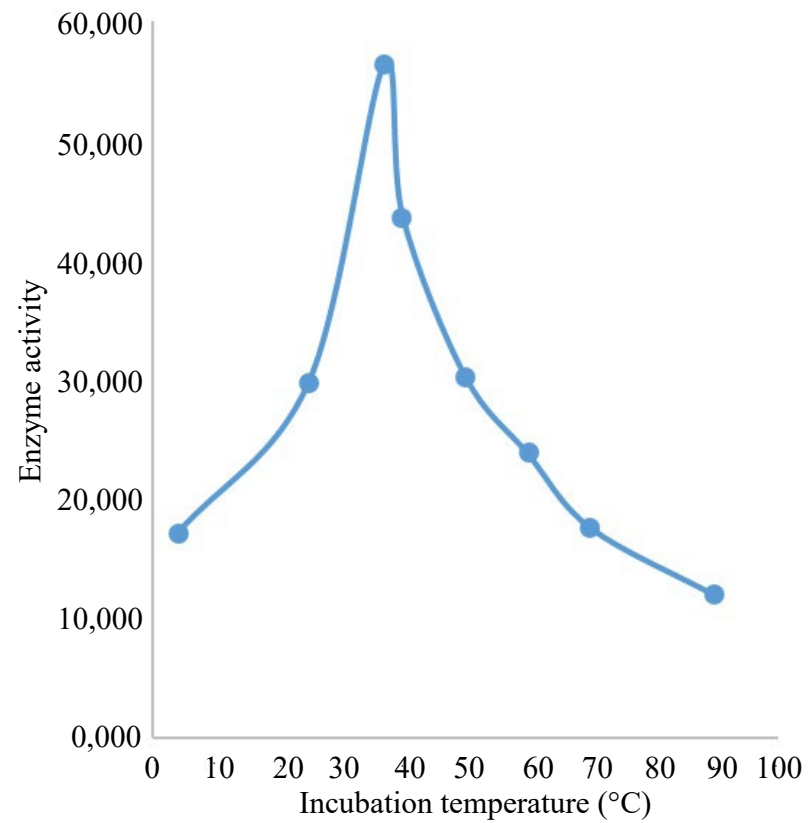

Figure 6. Effect of temperature on protease enzyme activity. Activity is presented in enzyme units

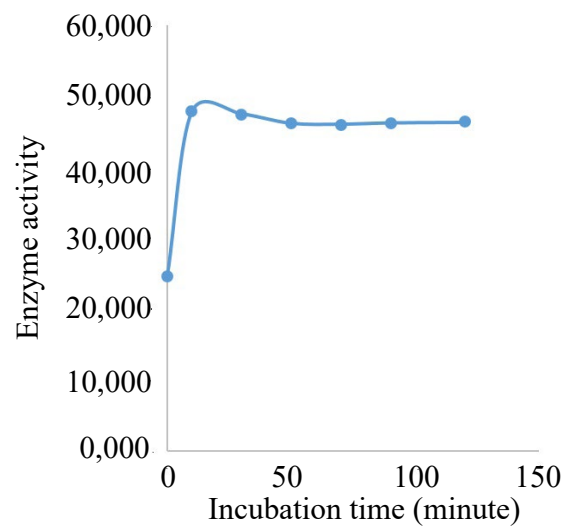

Figure 7. Effect of duration incubation time on protease enzyme activity. Activity is presented in enzyme units
Table 2. Enzyme activity after incubation with various metal ions and protease inhibitors

\begin{tabular}{lclc}
\hline Metals ion & $\begin{array}{l}\text { Relative } \\
\text { activity (\%) }\end{array}$ & Inhibitor & $\begin{array}{l}\text { Relative } \\
\text { activity (\%) }\end{array}$ \\
\hline Control & 100 & Control & 100 \\
ZnSO4 $1 \mathrm{mM}$ & 95 & Urea 1 mM & 97 \\
$\mathrm{ZnSO} 45 \mathrm{mM}$ & 97 & Urea 5 mM & 98 \\
$\mathrm{CaCl}_{2} 1 \mathrm{mM}$ & 97 & Iodoasetat 1 mM & 97 \\
$\mathrm{CaCl}_{2} 5 \mathrm{mM}$ & 88 & Iodoasetat 5 mM & 98 \\
$\mathrm{MgCl}_{2} 1 \mathrm{mM}$ & 90 & PMSF 1 mM & 33 \\
$\mathrm{MgCl}_{2} 5 \mathrm{mM}$ & 94 & PMSF 5 mM & 15 \\
$\mathrm{CuCl}_{2} 1 \mathrm{mM}$ & 92 & EDTA 1 mM & 96 \\
$\mathrm{CuCl}_{2} 5 \mathrm{mM}$ & 98 & EDTA 5 mM & 114 \\
\hline
\end{tabular}

Table 3. Enzyme activities after incubating with reducing and oxidizing agents

\begin{tabular}{lclc}
\hline $\begin{array}{l}\text { Oxidizing } \\
\text { agent }\end{array}$ & $\begin{array}{l}\text { Relative } \\
\text { activity (\%) }\end{array}$ & Reducing agent & $\begin{array}{l}\text { Relative } \\
\text { activity (\%) }\end{array}$ \\
\hline Control & 100 & Control & 100 \\
$\mathrm{H}_{2} \mathrm{O}_{2} 1 \mathrm{mM}$ & 50 & merkaptoetanol 1 mM & 91 \\
$\mathrm{H}_{2} \mathrm{O}_{2} 5 \mathrm{mM}$ & 41 & merkaptoetanol $5 \mathrm{mM}$ & 100 \\
\hline
\end{tabular}

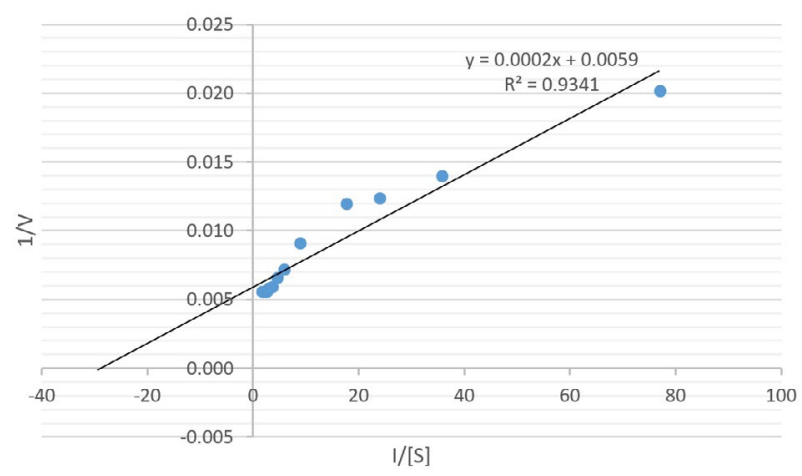

Figure 8. Lineweaver-burk curve

purified enzyme was more effective than crude enzyme.

\section{DISCUSSION}

Courgette protease isolation was carried out using ammonium sulfate with various saturations, namely $30 \%, 50 \%, 70 \%$, and $90 \%$. The highest protease activity was found in precipitates $70 \%$ saturation. This resembled with melon protease, which was precipitate $70 \%$ saturated (Devi and Hemalatha 2014). However, other member of Cucurbitaceae were precipitate in other saturation. Proteases from bitter gourd, cucumber, and chayote each precipitated in $40 \%, 90 \%$, and $50 \%$ (Wang et al. 2008; Ratnayani and Lia. 2011; Nafeesa et al. 2017). Fruits of other types such as pineapple require ammonium sulfate with $80 \%$ saturation to precipitate proteases in the test solution (Silvestre $e t$ al. 2012). Our result and melon protease suggested that the protease was probably have a small size, smaller than bitter gourd and chayote. We decided 

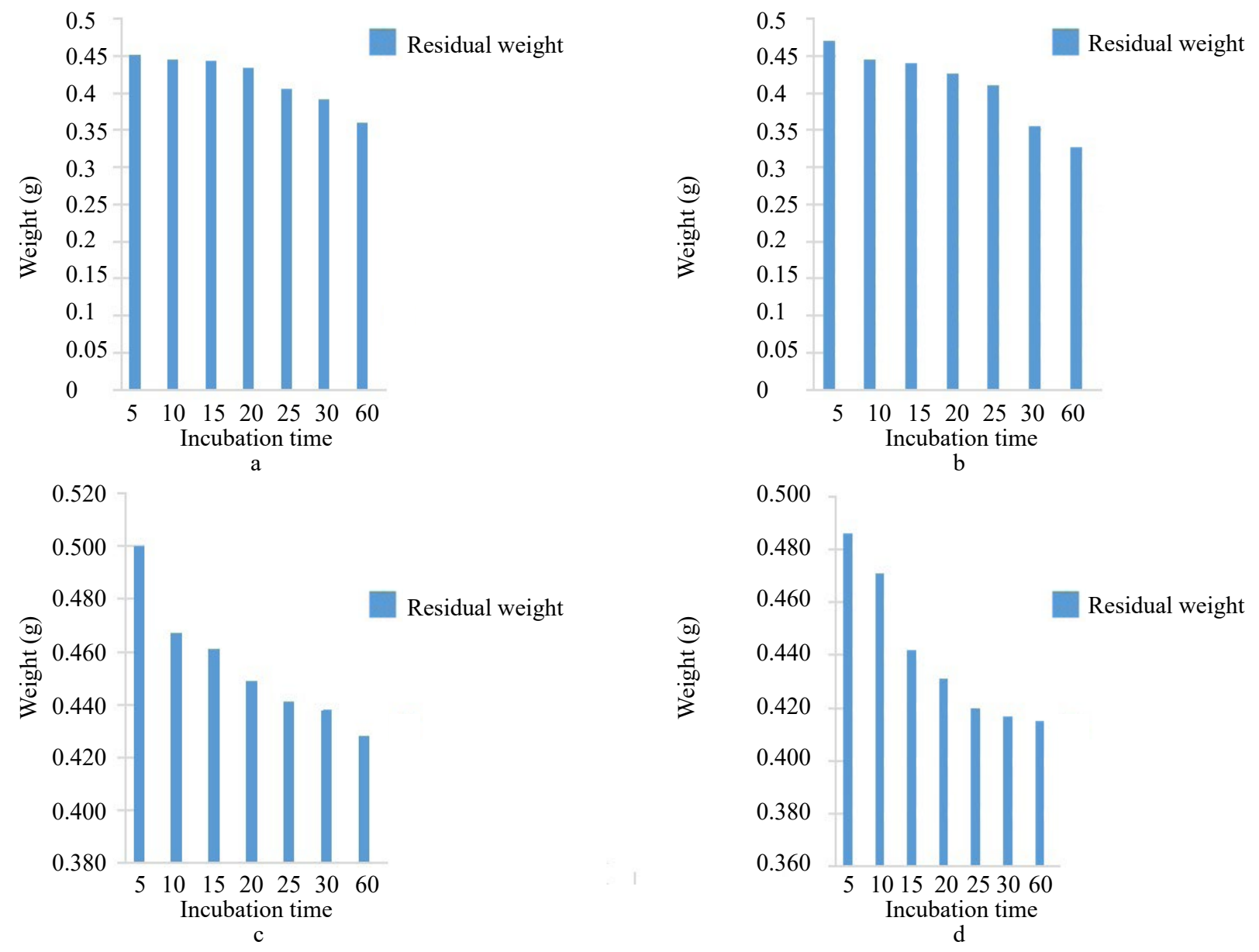

Figure 9. Results of depreciation the weight of boiled meat and eggs after incubation with crude and purified protease from courgette. (a) weight reduced of boiled meat after incubation with crude, (b) weight reduced of boiled meat after incubation with purified protease, (c) weight reduced of boiled white egg after incubation with crude, (d) weight reduced of boiled white egg after incubation with purified protease

Table 4. Free tyrosine concentrations in boiling meat and boiling white egg medium various time of incubation $(\mu \mathrm{g} / \mathrm{ml})$

\begin{tabular}{cccrc}
\hline $\begin{array}{c}\text { Time } \\
\text { (Minute) }\end{array}$ & $\begin{array}{c}\text { Boiled } \\
\text { beef } \\
\text { (crude) }\end{array}$ & $\begin{array}{c}\text { Boiled beef } \\
\text { (pure protease) }\end{array}$ & $\begin{array}{c}\text { Boiled } \\
\text { white egg } \\
\text { (crude) }\end{array}$ & $\begin{array}{c}\text { Boiled white } \\
\text { egg } \\
\text { (pure protease) }\end{array}$ \\
\hline 5 & 149,102 & 121,463 & 90,491 & 80,907 \\
10 & 242,528 & 135,213 & 125,676 & 87,852 \\
15 & 237,574 & 148,963 & 129,102 & 99,287 \\
20 & 237,343 & 170,769 & 172,620 & 99,333 \\
25 & 251,509 & 170,954 & 172,667 & 138,361 \\
30 & 258,083 & 172,991 & 182,250 & 104,704 \\
60 & 256,741 & 177,667 & 199,380 & 113,824 \\
\hline
\end{tabular}

to use the $70 \%$ as a starting material for following process.

Courgette protease purification using two types of chromatography, that are DEAE cellulose ion exchange chromatography and gel filtration chromatography using sephadex G-100 and G-75. Research using two types of sephadex was also carried out on the purification of proteases from melons (Devi and Hemalatha 2014). The results obtained from gel filtration chromatography produced the higher specific activity and more purer than cellulose DEAE. The disadvantage of using two types of chromatography is make the sample more dilute. this is proven by zymogram (Figure $4 b)$ which shows a smaller specific zone when the protease is successfully purified. Proteases that have been purified from gel filtration chromatography using sephadex G-75 produce a single band with a molecular weight of $34 \mathrm{kDa}$ after separation using non-electrophoresis denaturation (Figure 4).

Table 2 shows the effect of metal ions and protease inhibitors on protease activity. Metal ions on protease activity especially metalloproteinase is acting as electrophiles in enzymes, metal ions play a role to help attach the substrate to the enzyme and act as electron donors in oxidation-reduction reactions (Riordan et al. 1977). Courgette protease apparently was not a metalloproteinase, as indicated by no influence of metal ions on the action (Table 2). Iodoacetate had also no influenced, which suggested that courgette enzyme was not a cysteine protease. It is well known that iodoacetate can react with -SHgroup and replace the hydrogen with iodoacetate. If the - $\mathrm{SH}$ - group is found in active site like cysteine 
protease, the enzyme activity will be reduced and it was not found in our observation. Several plant proteae, like bromelain and papain are cysteine protease (Amri and Mamboya 2012; Fadhilah et al. 2018). However, several studies regarding protase Cucurbitaceae that have been reported, no fruit of Cucurbitaceae is belonging to the cysteine protease was found. PMSF had a remarkable decrease of our enzyme. This fact suggested that courgette protease was probably a serine protease, as PMSF is well known as serine protease inhibitor (Sharma and Radha 2011). Some Cucurbitaceae fruits that have been reported include serine proteases such as melon, pumpkin, cucumber and chayote. (Ratnayani and Lia 2011; Dạbrowska et al. 2013; Devi and Hemalatha 2014; Nafeesa et al. 2017).

The effect of oxidizing and reducing agent to courgette activity are show in Table 3 . From this result known that courgette protease can oxidized by $\mathrm{H}_{2} \mathrm{O}_{2}$, its was demonstrated that courgette protease had the free thiol group in its side chain amino acid. $\mathrm{H}_{2} \mathrm{O}_{2}$ can oxidizing thiol group so that release $\mathrm{H}_{2} \mathrm{O}$ and -S-S- bridge, this condition would make the activity of enzyme reduce (Zeida et al. 2012). Mercaptoethanol is act to reducing agent because could make the cleavage of disulfide bridge in protein structure, its can effect to native protein structure. In our obervation, mercaptoethanol had no influence to make a reducing activity protease, its known that courgette protease had no disulfide bridge in their structure (Scigelova et al. 2001).

The $\mathrm{Km}$ and Vmax value were determined using a gelatin substrate in various concentrations of 0.014-0.555 M. Lineweaver-Burk line equation was constructed and gave an equation $\mathrm{y}=0.0002 \mathrm{x}$ +0.0059 . which resulted $\mathrm{Km}$ value of $0.0339 \mathrm{M} / \mathrm{ml}$ and Vmax value of 164,491 U/M/minute. Courgette Protease had a Km value greater than the cucumber protease as much as $2.1 \times 10-4 \mathrm{M} / \mathrm{ml}$ (Nafeesa et al. 2017) $\mathrm{Km}$ is reflects the enzyme affinity to the substrate. The smaller $\mathrm{Km}$ value shows that the greater the affinity. Vmax is indicated the maximum capacity of an enzyme in catalyzing the substrate. (Sadikin 2002; German et al. 2011).

Courgette protease enzymes had the ability to digest food proteins properly. This was demonstrated by experiments with food protein materials in the form of beef and boiled egg whites which incubated with courgette crude as well as purified enzymes. Both form enzyme worked on both food materials and purified enzyme worked better than raw enzyme. These result were demonstrated by weight reduction and the increase of trypsin release in supernatant of medium (Figure 9). Purified courgette's protease can reduced beef meat as much as $0.173 \mathrm{~g}$ or $36.4 \%$ for 1 hours. The other research was reported that papain and bromelain can digest beef meat as much as $25.46 \%$ and $26.81 \%$ in less than 24 hours. (Istrati et al. 2012) In this case the courgette protease is better than bromelain and papain in digesting food proteins. Trypsin and pepsin had the ability to beef meat as much as $80 \%$ for 2 hours (Wen et al. 2015). This report is show that trypsin and pepsin is better that courgette protease in digesting food protein materials (Wen et al. 2015). The ability of courgette protease to digest food protein is also demonstrated by increase tyrosine release in supernatant of medium (Table 4). The greater of reducing sample's weight is more tyrosine release into supernatant. Courgette's crude can release tyrosine in medium as much as $256,741 \mu \mathrm{g} / \mathrm{ml}$ after reacting with boiled beef, while purified curgette protease is able to release tyrosine to the medium as much as $177,667 \mu \mathrm{g} / \mathrm{ml}$. Both of these results indicate that courgette proteases better digest boiled beef proteins compared to boiled egg whites which only release tyrosine at $199,380 \mu \mathrm{g} / \mathrm{ml}$ by crude and $113,824 \mu \mathrm{g} / \mathrm{ml}$ by purified courgette proteases.

From all the experiments of this research, it can be concluded that the courgette protease is a serine protease and can be active optimally at neutral $\mathrm{pH}$, $37^{\circ} \mathrm{C}, 10$ minute duration time and had lower $\mathrm{Km}$ value than cucumber $\mathrm{Km} . \mathrm{H}_{2} \mathrm{O}_{2}$ had influence to make courgette activity was decrease. Its mean that courgette protease has thiol group in its structure. The ability to digest protein better than bromelain and papain, but is not better than pepsin and trypsin. This shows that courgette proteases could be used in enzyme replacement therapy in mild digestion problem but still need to be studied further about their application as proteases which act like digestive proteases. Finally, to get better result from courgette's protease we should more explore about the purification technique and characteristic to get purified protease with high concentrate and to know more about the type of courgette protease.

\section{ACKNOWLEDGEMENTS}

I am very grateful to Prof. dr. Mohamad Sadikin, D.Sc and Dr. drg. Dwirini Retno Gunarti, MS who has taken the time to guide and provide very helpful advice. To biochemistry and Molecular Biology the department has provided facilities and infrastructure for this research. 


\section{REFERENCES}

Amri E, Mamboya F. 2012. Papain, a plant enzyme of biological importance: a review. American Journal of Biochemistry and Biotechnology 8:99-104.

Asker M, Manal GM, Khalid ES, Mohamed SAEA. 2013. Purification and characterization of two thermostable protease fractions from bacillus megaterium. Journal of Genetic Engineering and Biotechnology 11:103-109. http://dx.doi.org/10.1016/j.jgeb.2013.08.001

Dạbrowska A, Szołtysik M, Babij K, Pokora M, Zambrowicz A, Chrzanowska J. 2013. Application of Asian pumpkin (Cucurbita ficifolia) serine proteinase for production of biologically active peptides from casein. Acta Biochim Pol 60:117-122.

Devi BG, Hemalatha KPJ. 2014. Isolation, partial purification and characterization of alkaline serine protease from seeds of cucumis melo var agrestis. International Journal of Research in Engineering and Technology:88-97.

Fadhilah Y, Aliyah S, Siswati S, Sri H. 2018. The Effect of $\mathrm{Ca}^{2+}, \mathrm{Mg}^{2+}$ ions , Cysteine, and Benzoic Acid on the Activity of Purified Bromelain from Pineapple Core Extract (Ananas Comosus [ L ]. Merr ). AIP Conference Proceedings 020033.

German DP, Weintraubb MN, Grandy AS, Lauber CL, Rinkes ZL, Allison AE. 2011. Optimization of hydrolytic and oxidative enzyme methods for ecosystem studies. Soil Biology and Biochemistry 43:1387-1397.

Gunarti DR. 1997. Isolasi Dan Purifikasi Fosfatase Asam Dari Air Kelapa (Cocos Nucifera Linn). Universitas Indonesia.

Istrati D, Vizireanu C, Dima F, Dinic R. 2012. Effect of marination with proteolyitic enzyme on quality of beef muscle. Scientific Study and Research: Chemistry and Chemical Engineering 13:81-89.

Ketnawa S, Phanuphong C, Saroat R. 2011. Extraction of bromelain from pineapple peels. Food Science and Technology International 17:395-402.

Nafeesa Z, Shivalingu BR, Neema KN, Achar RR, Venkatesh BK, Hanchinal V, Priya BS, Nanjunda SS. 2017. Procoagulant serine glycoprotease from Cucumis sativus L.: action on human fibrinogen and fibrin clot. 3 Biotech 7:1-11.
Naidu KS. 2011. Characterization and purification of protease enzyme. Journal of Applied Pharmaceutical Science $1: 107-112$.

Ratnayani K, Lia K. 2011. Isolation of Protease enzyme from chayote fruit (sechium edule (Jacq.) Sw.) with ammonium sulfate fractination method. International Journal of Biosciences and Biotechnology 2:78-82.

Riordan JF, Veter B, Brigham Hospital. 1977. The role of metals in enzyme activity. Ann Clin Lab Sci 7:119-129.

Sadikin M. 2002. Biokimia Enzim. Jakarta: Widya Medika.

Scigelova M, Giannakopulos A, Green P, Rodger A. 2001. A practical protocol for the reduction of disulfide bonds in proteins prior to analysis by mass spectrometry. European Mass Spectrometry 7:29-34.

Sharma A, Radha KKV. 2011. Serine Protease Inhibitor Mediated Peptide Bond Re-Synthesis in Diverse Protein Molecules. FEBS Lett 585:3465-3470. http://dx.doi. org/10.1016/j.febslet.2011.10.004

Silvestre MPC, Carreira RL, Silva MR, Corgosinho FC, Monteiro MRP, Morais HA. 2012. Effect of $\mathrm{pH}$ and temperature on the activity of enzymatic extracts from pineapple peel. Food and Bioprocess Technology 5:1824-1831.

Sulistyowati E. Salirawati D, Amanatie. 2016. Karakterisasi beberapa ion logam terhadap aktivitas enzim tripsin. Jurnal Penelitian Saintek 21:107-120.

Wang L, Wang M, Li Q, Cai T, Jiang W. 2008. Partial properties of an aspartic protease in bitter gourd (Momordica Charantia L.) fruit and its activation by heating. Food Chem 108:496-502.

Wen S, Zhou G, Song S, Xu X, Voglmeir J, Liu L, Zhao F, Li M, Li L, Yu X, Bai Y, Li C. 2015. Discrimination of in vitro and in vivo digestion products of meat proteins from pork, beef, chicken, and fish. Proteomics 15:3688-3698.

Zeida A, Babbush R, Lebrero MC, Trujillo M, Radi R, Estrin DA. 2012. Molecular basis of the mechanism of thiol oxidation by hydrogen peroxide in aqueous solution: challenging the SN2 paradigm. Chem res toxicol 25:741-746. 